\title{
PENGARUH PERENDAMAN EKSTRAK DAUN MANGROVE (Sonneratia caseolaris) TERHADAP PENILAIAN MUTU ORGANOLEPTIK IKAN KUWE (Gnathanodon speciosus) SEGAR
}

\author{
(The Soaking Effect of Mangrove Leaf Extract (Sonneratia Caseolaris) on \\ The Organoleptic Quality Assessment of \\ Fresh Golden Trevally Fish (Gnathanodon Speciosus))
}

\author{
Nur A. Saimima*, Abdul Rahman, Desri N. Manuhutu \\ Prorgam Studi Pengolahan Hasil Laut Politeknik Kelautan dan Perikanan Maluku \\ nursaimima02@gmail.com,rahmandzaki89@gmail.com,edesmanuhutu@gmail.com \\ Corresponding author*
}

\begin{abstract}
ABSTRAK: Ikan merupakan bahan pangan yang sangat mudah mengalami kemunduran mutu terutama oleh aktivitas mikroorganisme pembusuk. Salah satu upaya untuk menghambat penurunan mutu ikan dengan menggunakan bahan alami yaitu daun mangrove. Penelitian ini bertujuan untuk mengetahui pemanfaatan ekstrak daun mangrove (Sonneratia caseolaris) terhadap mutu organoleptik ikan kuwe (Gnathanodon speciosus) segar. Penelitian dilakukan pada bulan Maret 2020 di Laboratorium Hatchery Laut dan Workshop Pengolahan SUPM Waiheru Ambon. Penelitian menggunakan metode experimental laboratories dengan tahapan-tahapan yaitu persiapan sampel, preparasi ekstrak daun mangrove, perendaman ikan kuwe dalam esktrak daun mangrove, penyimpanan, serta analisa data penilaian organoleptik. Penilaian organoleptik meliputi mata, insang, lendir permukaan badan, daging (warna dan kenampakan), bau serta tekstur dilakukan setiap 6 jam sekali sampai mutu ikan ditolak oleh panelis. Hasil penelitian menunjukan bahwa perendaman ekstrak daun mangrove dapat menghambat pertumbuhan mikroba pada ikan. Konsentrasi ekstrak daun mangrove $2 \%$ dan $4 \%$ dapat memperpanjang daya simpan ikan kuwe segar pada suhu kamar 6 jam lebih lama dibandingkan kontrol. Disamping itu, perlakuan perendaman ekstrak daun mangrove dapat mempertahankan nilai organoleptik ikan. Kesimpulannya Hasil penilaian mutu organoleptik ikan kuwe (Gnathanodon speciosus) segar dalam perlakuan perendaman ekstrak daun mangrove (Sonneratia caseolaris) dengan konsentrasi 2\%-4\% dapat mempertahankan daya simpan ikan kuwe. Hal ini disebabkan peran senyawa metabolik sekunder yang terkandung pada daun mangrove yang dapat menghambat pertumbuhan mikroba.
\end{abstract}

Kata Kunci: Sonneratia caseolaris, Gnathanodon speciosus, organoleptik, daun mangrove, ekstrak

ABSTRACT: Fish is a comestible that is inclined to the deterioration of quality, especially by the activity of rotting microorganisms. One of the efforts to obstruct the decline in fish quality by using natural ingredients, namely mangrove leaves. This study aims to determine the utilization of mangrove leaf extract (Sonneratia caseolaris) on the organoleptic quality of fresh golden trevally fish (Gnathanodon speciosus). The research was conducted in March 2020 at the Marine Hatchery Laboratory and Processing Workshop SUPM in Waiheru Ambon. The research used a laboratory experimental method with several stages, these were sample preparation, mangrove leaf extract preparation, immersion of golden trevally fish in mangrove leaf extract, storage, and analysis of organoleptic assessment data. Organoleptic assessments including eyes, gills, body surface slime, meat (color and appearance), smell and 
texture were carried out every 6 hours until the quality of the fish was rejected by the panelists. The results showed that soaking mangrove leaf extract can inhibit microbial growth in fish. The concentrations of mangrove leaf extract $2 \%$ and $4 \%$ could lengthen the shelf life of fresh golden trevally fish at room temperature for 6 hours longer than the control. In addition, the mangrove leaf extract immersion treatment can maintain the organoleptic value of fish. In conclusion, the results of the organoleptic quality assessment of fresh golden trevally fish (Gnathanodon speciosus) in soaking treatment of mangrove leaf extract (Sonneratia caseolaris) with a concentration of $2 \%-4 \%$ can maintain the shelf life of golden trevally fish. This is due to the role of secondary metabolic compounds contained in mangrove leaves which can inhibit microbial growth.

Keywords: Sonneratia caseolaris, Gnathanodon speciosus, organoleptic, mangrove leaves, extract

\section{PENDAHULUAN}

Kesegaran ikan merupakan faktor utama yang menentukan mutu dan daya awet produk yang akan diolah (Wibowo, dkk., 2014; Suprayitno, 2020) . Hasil perikanan yang baru dipanen, cepat sekali mengalami penurunan mutu yang menjurus ke arah penguraian dan pembusukan (Sadiki, dkk., 2015). Penyebab utama penurunan mutu adalah aksi enzimatik, kimiawi dan bakterial dan sangat dipengaruhi oleh faktor suhu. Setelah proses penangkapan dilakukan, kesegaran ikan akan munurun jika tidak ditangani dengan baik sehingga akan menurunkan kualitas produk. Hal ini akan terlihat dengan terjadinya perubahan sifat organoleptik yaitu rupa, bau, citarasa dan teksturnya (Nurqaderianie, $d k k .$, 2016). Hingga saat ini, penanganan dengan suhu rendah (chiling) merupakan teknik penanganan ikan yang paling banyak digunakan. Penggunaan es umumnya bertujuan untuk mempertahankan kesegaran ikan selama maupun dalam distribusi. Pada suhu kamar $\left( \pm 25^{\circ}\right)$, ikan umumnya hanya bertahan antara 6-12 jam, sedangkan dengan perlakuan es maka mutu ikan dapat dipertahankan hingga 1-2 minggu (Putro, $d k k$., 2008).

Ikan kuwe (Gnathanodon speciosus) merupakan salah satu sumberdaya perikanan yang yang mempunyai pangsa pasar cukup tinggi dan sering dipasarkan dalam bentuk segar, sehingga memerlukan penanganan yang baik untuk menghambat proses pembusukan. Cara untuk menghambat proses pembusukan ikan adalah dengan pengawetan. Proses pengawetan ikan merupakan salah satu bagian penting dari mata rantai industri perikanan (Tuyu, dkk., 2014). Pengawetan bertujuan mempertahankan kesegaran ikan selama mungkin dengan cara menghambat penyebab kemunduran mutu. Mutu kesegaran ikan dapat diamati dari rupa atau kenampakan, rasa, bau dan tekstur sehingga perlu pengamatan secara organoleptik untuk mengetahui tingkat kesegaran ikan. Dalam teknologi pengolahan pangan, berbagai usaha telah dilakukan untuk menjaga daya simpan hasil perikanan segar, sehingga muncul bahan-bahan pengawet yang bertujuan untuk memperpanjang masa simpan. Namun dalam praktiknya, masih banyak terjadi penyimpangan penggunaan bahan pengawet yang berbahaya bagi kesehatan dan sudah dilarang (Girsang et al., 2014)

Salah satu alternatif untuk menghambat penurunan mutu ikan adalah dengan menggunakan produk alami misalnya mangrove (Pariansyah, $d k k .$, 2018). Tumbuhan mangrove selain mempunyai fungsi sebagai penunjang kehidupan biota air untuk tempat pembiakan dan pembesaran, fungsi perlindungan pantai dari abrasi serta pemanfaatannya bagi masyarakat pesisir sebagai bahan makanan, minuman dan obat-obatan, tumbuhan mangrove juga memiliki kandungan senyawa antibakteri terbanyak pada bagian daunnya akibat dari proses fotosintesis (Saptiani, dkk., 2013). Penelitian juga dilakukan pada daun pidada merah (Sonneratia caseolaris) yang memiliki aktivitas antioksidan dengan kandungan metabolit sekundernya yaitu senyawa fenolik, 
flavonoid, saponin, karatenoid dan tannin (Hasana, dkk., 2015)

Penelitian juga dilakukan pada buah mangrove Avicennia marina yang memiliki senyawa bioaktif terhadap tingkat oksidasi fillet ikan nila merah (O. niloticus) selama penyimpanan dingin (Sipayung, dkk., 2015) Hasil penelitian menunjukan bahwa buah mangrove Avicennia marina dapat digunakan sebagai antioksidan pada fillet ikan nila merah (O. niloticus) yang disimpan dingin. Hasil penelitian lainnya juga menunjukkan bahwa ekstrak rumput laut (Eucheuma spinosum) dan ekstrak buah bakau (Sonneratia alba) yang direndam menggunakan es dapat digunakan dalam menghambat pertumbuhan mikroba pada ikan agar tidak cepat mengalami kerusakan (Pianusa, $d k k$., 2015). Hasil penelitian menyatakan. Maserat serbuk buah mangrove Avicennia marina juga memiliki nilai organoleptik lebih tinggi daripada buah mangrove selama masa simpan ikan nilai segar (Pariansyah, dkk., 2018). Berdasarkan uraianuraian tersebut maka perlu dilakukan penelitian yang bersifat eksploratif terhadap bagian daun jenis mangrove Sonneratia caseolaris untuk meningkatkan mutu ikan. Penelitian ini bertujuan untuk mengetahui pemanfaatan ekstrak daun mangrove (Sonneratia caseolaris) terhadap mutu organoleptik ikan kuwe (Gnathanodon speciosus) segar.

\section{METODE PENELITIAN}

Kegiatan penelitian ini dilakukan pada bulan Maret 2020 di Laboratorium Hatchery Laut dan Workshop Pengolahan SUPM Waiheru Ambon. Penelitian dilakukan dengan menggunakan metode experimental laboratories dengan tahapan-tahapan yaitu persiapan sampel, preparasi ekstrak daun mangrove, perendaman ikan kuwe dalam esktrak daun mangrove, penyimpanan, serta analisa data penilaian organoleptik. Bahan yang digunakan pada proses ini adalah ikan kuwe (Gnathanodon speciosus) hidup berukuran 350-300 gram/ekor dengan panjang 35-30 $\mathrm{cm}$ yang diperoleh dari Keramba Jaring Apung (KJA) milik SUPM Negeri Waiheru Ambon sedangkan daun mangove (Sonneratia caseolaris) segar diperoleh dari sekitar pantai Teluk Ambon khususnya berlokasi di Waiheru. Peralatan yang digunakan selain peralatan laboratorium adalah Freezer, ember, pisau, blender, wadah plastik berbentuk bundar yang berdiamater $30 \mathrm{~cm}$ dan peralatan lainnya yang diperlukan.

\section{Persiapan sampel}

Ikan kuwe hidup diambil dari keramba jaring apung (KJA) dengan menggunakan teknik transportasi basah yakni ikan dimasukkan dalam ember yang diberi air laut kemudian dibawa menuju Laboratorium Hatchery Laut SUPM Waiheru Ambon. Selanjutnya sampel ikan yang diperoleh diberi kode. Pemilihan ikan hidup didasarkan pada pertimbangan agar diperoleh data kesegaran ikan yang prima (segera setelah ikan mati). Dalam pengkajian ini tidak dilakukan penyiangan pada ikan kuwe namun dibiarkan selama kurang lebih 15 menit hingga ikan mati. Daun mangrove yang telah dipetik kemudian langsung dicuci hingga bersih dan ditiriskan.Daun mangrove disimpan dalam freezer dengan suhu $50^{\circ} \mathrm{C}$ selama satu malam sebelum diekstrak.

\section{Preparasi Ekstrak Daun Mangrove}

Ekstrak daun mangrove dibuat berdasarkan metode yang digunakan oleh Haryati (2006). Pada pengkajian ini dilakukan 3 perendaman konsentrasi ekstrak daun mangrove yang berbeda yaitu $0 \%, 2 \%$ dan $4 \%$. Untuk mendapatkan ekstrak daun mangrove dengan konsentrasi $2 \%$ yaitu sebanyak 200 gram daun mangrove diblender terlebih dahulu, kemudian dilarutkan dalam 10 liter air. Larutan ekstrak daun mangrove tersebut diaduk hingga homogen dan kemudian didiamkan selama 15 menit, setelah itu larutan ekstrak daun mangrove disaring dari ampasnya.

\section{Perendaman Ikan Kuwe Dalam Ekstrak Daun Mangrove dan Penyimpanan}

Ikan kuwe dimasukkan dalam wadah plastik berbentuk bundar berdiamater $30 \mathrm{~cm}$. Kemudian sebanyak 3 liter larutan ekstrak daun mangrove dituang ke ikan hingga seluruh permukaan ikan terendam masing-masing pada konsentrasi yang berbeda. Ikan yang telah direndam kemudian disimpan pada ruangan 
tertutup agar tidak terkontaminasi atau terhindar dari lalat dengan suhu kamar yaitu $28-30^{\circ} \mathrm{C}$ selama 24 jam. Selanjutnya dilakukan penilaian mutu organoleptik setiap 6 jam sekali sampai mutu ikan ditolak oleh panelis.

\section{Analisa Data Penilaian Organoleptik}

Penilaian mutu organoleptik dilakukan oleh 6 orang panelis terlatih yang penilaiannya didasarkan kriteria acuan SNI 01-2729.1-2006. Penilaian meliputi mata, insang, lendir permukaan badan, daging (warna dan kenampakan), bau serta tekstur. Pengujian organoleptik merupakan cara atau teknik pengujian dengan menggunakan indera manusia sebagai alat utama dalam menilai mutu ikan hidup dan produk perikanan yang masih dalam keadaan segar utuh (Wahyu, $d k k$. 2019).

\section{HASIL DAN PEMBAHASAN}

\section{Pengujian Organoleptik}

Hasil pengujian menunjukkan bahwa perlakuan perendaman dalam larutan ekstrak daun mangrove berpengaruh nyata terhadap penilaian mutu organoleptik ikan kuwe. Perendaman ikan kuwe dalam ekstrak daun mangrove memberikan nilai organoleptik yang lebih baik dibandingkan kontrol. Begitu juga dengan perlakuan konsentrasi pada daun mangrove, semakin tinggi konsentrasi ekstrak yang digunakan, nilai mutu organoleptiknya dapat dipertahankan. Ekstrak daun mangrove terbukti dapat mempertahankan insang dan bau daging ikan. Seluruh ikan hasil perlakuan perendaman ekstrak daun mangrove ditolak panelis pada jam ke-24, sedangkan perlakuan kontrol ditolak pada jam ke-18.

\section{Mata}

Salah satu indikator kesegaran ikan terletak pada bagian mata. Menurut Pianusa, dkk. (2015) salah satu ciri kemunduran mutu ikan yaitu berubahnya kondisi mata ikan menjadi terbenam dan pudar akibat adanya aktivitas bakteri pembusuk. Nilai rata-rata organoleptik mata untuk ketiga perlakuan perendaman konsentrasi ekstrak daun mangrove pada jam 0 adalah 9. Hal ini menunjukkan bahwa penyimpanan 0 jam, keadaan ikan termasuk kategori sangat segar dan tidak ada perbedaan, karena secara organoleptik mata cerah, bola mata masih menonjol dan kornea jernih.

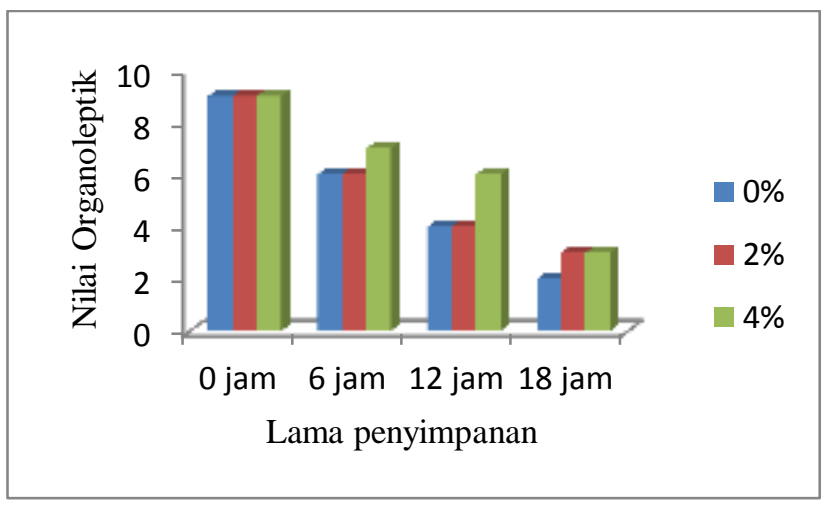

Gambar 1. Histogram penilaian organoleptik pada mata (eye)

Pada penyimpanan selama 6 jam, terlihat bahwa ikan dengan perendaman 0 dan $2 \%$ memiliki nilai rata-rata sama yaitu 7,90 . Penialaian pada bagian mata secara organoleptik yaitu mata agak cerah, bola mata rata, pupil agak keabu-abuan dan kornea jernih. Sedangkan untuk ikan dengan perendaman $4 \%$ memiliki nilai rata-rata 8,95. Keadaan mata cerah, bola mata menonjol dan kornea mata jernih. Hal ini menunjukkan bahwa pada lama penyimpanan 6 jam secara organoleptik mata mengalami penurunan. Pada ikan segar, bola mata ikan terlihat cembung dan cerah (Pariansyah, dkk., 2018).

Pada penyimpanan 12 jam, terlihat bahwa ikan dengan perendaman 0 dan $2 \%$ memiliki rata-rata sama yaitu 6,00 dengan kenampakan bola mata agak cekung, pupil berubah keabuabuan dan kornea agak keruh. Sedangkan untuk ikan dengan perendaman $4 \%$ memiliki nilai rata-rata 7 dengan ciri yang terlihat yaitu bola mata rata, pupil sedikit berubah keabu-abuan dan kornea masih jernih. Hal ini menunjukkan bahwa pada penyimpanan 12 jam secara organoleptik ikan dengan perendaman 0 dan $2 \%$ mengalami penurunan cukup banyak sehingga perubahan mutu sangat mencolok. Namun dengan perendaman $4 \%$ masih belum menunjukkan perubahan yang cukup signifikan. Hal ini dikarenakan ekstrak daun mangrove dapat menghambat pertumbuhan mikroba. 
Pada penyimpanan 18 jam, terlihat ikan dengan perendaman $0 \%$ memiliki rata-rata 3,00 dengan kenampakan bola mata sudah cekung, pupil telah berubah menjadi putih susu dan kornea sudah keruh. Untuk ikan dengan perendaman $2 \%$ memiliki rata-rata 4,00 dengan ciri-ciri bola mata cekung, pupil keabu-abuan dan kornea keruh. Sedangkan ikan dengan perendaman $4 \%$ memiliki rata-rata 6,00 yang organoleptiknya pada bola mata agak cekung, pupil sedikit berubah keabu-abuan dan kornea sedikit keruh. Secara keseluruhan, hasil penilaian organoleptik menunjukan bahwa semakin banyak ekstrak daun mangrove yang diberikan maka nilai rata-rata organoleptik semakin baik. Ikan dengan perendaman 0 dan $2 \%$ tidak memunculkan adanya perbedaan yang cukup jauh. Nilai rata-rata organoleptik mata sudah mengalami penurunan mutu sehingga tidak bisa diterima lagi dan tidak aman untuk dikonsumsi.

\section{Insang}

Insang merupakan salah satu parameter kesegaran ikan, namun insang juga merupakan salah satu tempat hidup bakteri yang dapat menyebabkan kerusakan pada daging ikan. (Pariansyah, $d k k .$, 2018). Oleh karena itu insang dapat dijadikan salah satu parameter kesegaran ikan. Nilai rata-rata organoleptik insang untuk ketiga perlakuan perendaman konsentrasi ekstrak yang berbeda pada jam 0 adalah 9 (Gambar 2). Hal ini menunjukkan bahwa pada penyimpanan 0 jam, ikan termasuk dalam kategori sangat segar dan tidak ada perbedaan, karena secara organoleptik warna insang merah cemerlang dan tanpa lendir.

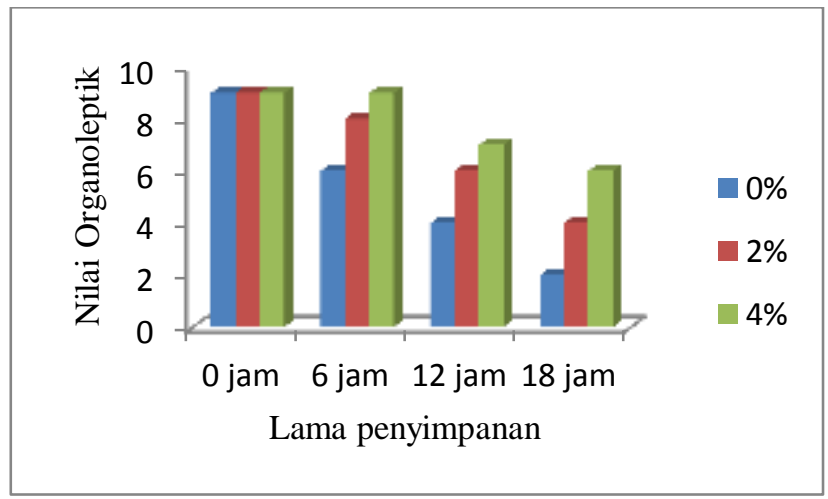

Gambar 2. Histogram penilaian organoleptik pada insang ( illl)
Pada penyimpanan 6 jam dengan konsentrasi perendaman $0 \%$ memiliki nilai ratarata sama yaitu 7,00 yang secara organoleptik terlihat kondisi insang agak kusam dan mulai berlendir. Ikan dengan perendaman 2\% memiliki rata-rata yaitu 8,00 yang secara organoleptik kondisi insang agak berubah menjadi kurang cemerlang dan belum berlendir. Sedangkan untuk ikan dengan perendaman $4 \%$ memiliki nilai rata-rata 8,90 yang organoleptik insang masih berwarna merah cemerlang dan belum berlendir. Hal ini menunjukkan bahwa pada penyimpanan 6 jam secara organoleptik kondisi insang pada ikan dengan perendaman 4\% belum mengalami penurunan potensi ekstrak dalam menghambat mikroba khususnya pada insang cukup baik.

Pada penyimpanan 12 jam, terlihat bahwa ikan dengan perendaman $0 \%$ memiliki rata-rata 3,90 yang organoleptik insang sudah berwarna coklat, insang berlendir tebal serta diikuti bau busuk. Ikan dengan perendaman $2 \%$ memiliki rata-rata sama yaitu 6,00 yang organoleptik insang berwarna merah kusam dan insang mulai berlendir. Sedangkan untuk ikan dengan perendaman $4 \%$ memiliki nilai rata-rata 7,00 yang organoleptik insang berwarna merah agak kusam dan belum berlendir. Hal ini menunjukkan bahwa pada penyimpanan 12 jam secara organoleptik, kondisi ikan pada insang dengan perendaman $4 \%$ sedikit mengalami penurunan sehingga belum terjadi perubahan mutu. Dapat dikatakan bahwa secara organoleptik insang, ikan tersebut masih dapat dikonsumsi.

Pada penyimpanan 18 jam, terlihat ikan dengan perendaman $0 \%$ memiliki rata-rata 2,00 yang organoleptik insang berwarna coklat tua dan berlendir tebal menutupi seluruh bagian insang. Ikan dengan perendaman $2 \%$ memiliki rata-rata 4,00 yang organoleptik insang berwarna coklat muda dan berlendir. Sedangkan ikan dengan perendaman $4 \%$ memiliki rata-rata 6,00 yang organoleptik insang masih berwarna merah kusam dan tanpa lendir.

Berdasarkan hasil penilaian organoleptik insang, dapat disimpulkan bahwa semakin banyak ekstrak yang diberikan maka nilai ratarata organoleptik semakin baik. Untuk ikan dengan perendaman 0 dan $2 \%$ terlihat adanya 
perbedaan yang cukup jauh dan untuk nilai ratarata organoleptik insang sudah mengalami penurunan mutu sehingga tidak bisa diterima lagi dan tidak aman untuk dikonsumsi. Menurut Tapotubun, dkk. (2016) menyatakan bahwa keberadaan bakteri secara alami pada ikan terkonsentrasi pada isi perut, insang dan kulit. Jumlah bakteri pada ikan bervariasi tergantung media dimana bakteri itu hidup, yaitu diantara $10^{2-} 10^{5}$ /gr pada kuilit, $10^{3-} 10^{5}$ /gr pada insang dan dapat mencapai $10^{7} / \mathrm{gr}$ pada isi perut. Berdasarkan seluruh penilaian mutu organoleptik pada insang, maka dapat dikatakan bahwa perubahan warna pada insang itu dapat terjadi akibat peningkatan jumlah bakteri. Kaitannya dengan penelitian ini, bahwa perubahan nilai organoleptik insang pada ikan yang direndam dalam ekstrak daun mangrove dengan ikan tanpa direndam pada penyimpanan 18 jam rata-rata secara drastis jauh berbeda. Ikan yang direndam memiliki nilai rata-rata organoleptik sebesar 2,00 dan untuk ikan tanpa direndam mempunyai nilai rata-rata organoleptik sebesar 6,00 .

\section{Lendir}

Menurut Pariansyah, $d k k$. (2018) bahwa terbentuknya lendir merupakan tanda awal terjadinya proses kemunduran mutu (fase prerigor). Nilai rata-rata organoleptik lendir untuk ketiga perlakuan perendaman konsentrasi ekstrak yang berbeda pada jam 0 adalah 9 (Gambar 3). Hal ini menunjukkan bahwa pada penyimpanan 0 jam, ikan termasuk dalam kategori sangat segar dan tidak ada perbedaan. Dapat dikatakan, secara organoleptik ikan masih belum berlendir dan kulit berwarna cerah.

Pada penyimpanan 6 jam, terlihat bahwa ikan dengan perendaman $0 \%$ memiliki nilai rata-rata sama yaitu 7,00 . Secara organoleptik lendir mulai keluar dan terlihat mulai agak keruh, warna agak kusam serta kurang transparan. Ikan dengan perendaman 2\% memiliki nilai rata-rata yaitu 8,00 yang secara organoleptik terlihat lendir masih jernih, kulit transparan, cerah dan belum ada perubahan warna. Sedangkan untuk ikan dengan perendaman $4 \%$ memiliki nilai rata-rata 8,90 yang secara organoleptik lendir jernih, transparan dan kulit masih cerah.

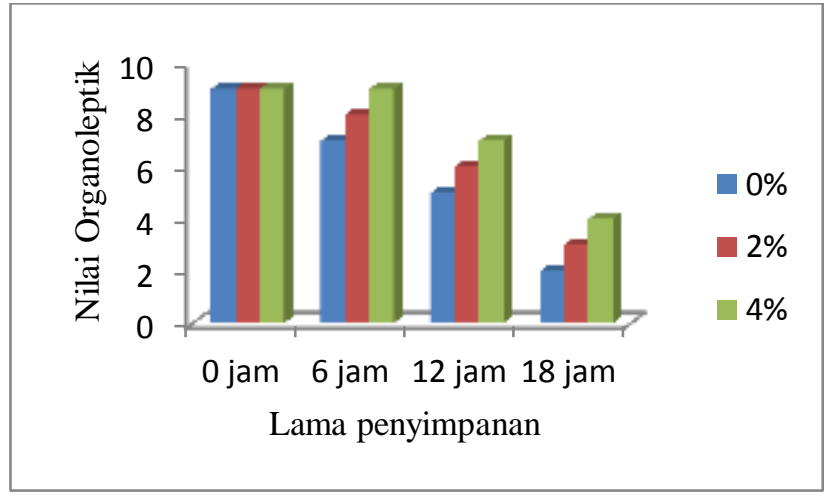

Gambar 3. Histogram penilaian organoleptik pada lender (slime)

Pada penyimpanan 12 jam, terlihat bahwa ikan dengan perendaman $0 \%$ memiliki nilai rata-rata 5,00 yang secara organoleptik lendir tebal mengumpal dan mulai berubah menjadi keruh. Ikan dengan perendaman $2 \%$ memiliki rata-rata yaitu 6,00 yang organoleptik lendir mulai keruh dan agak kusam serta kulit kurang transparan. Sedangkan untuk ikan dengan perendaman $4 \%$ memiliki nilai rata-rata 7,00 yang organoleptik terlihat lendir mulai agak keruh dan warna kulit kurang transparan. Hal ini menunjukkan bahwa pada penyimpanan 12 jam secara organoleptik pada lendir ikan dengan perendaman $4 \%$ mengalami penurunan sehingga ikan sudah tidak dapat dikonsumsi lagi.

Pada penyimpanan 18 jam, terlihat ikan dengan perendaman $0 \%$ memiliki nilai rata-rata 2,00 dengan ciri-ciri lendir tebal, mengumpal dan berwarna kuning kecoklatan. Ikan dengan perendaman $2 \%$ memiliki rata-rata 3,00, dengan lendir tebal, mengumpal dan berwarna putih kekuning-kuningan. Sedangkan ikan dengan perendaman $4 \%$ memiliki nilai rata-rata 4,00 dimana terlihat lendir yang tebal mengumpal dan mulai berubah putih agak keruh.

Menurut Adawyah (2008), ikan yang masih segar mempunyai kenampakan cerah dan tidak suram. Keadaan itu dikarenakan belum banyak perubahan biokimia yang terjadi. Metabolisme dalam tubuh ikan masih berjalan sempurna. Pada ikan tidak ditemukan tandatanda perubahan warna, tetapi secara berangsurangsur warna makin suram, karena timbulnya lendir sebagai akibat berlangsungnya proses biokimia lebih lanjut dan berkembangnya mikroba. 


\section{Daging}

Menurut Adawyah (2007), salah satu hasil aktivitas bakteri pembusuk terlihat pada daging ikan. Perubahan warna daging mulai dari sekitar tulang belakang karena suhu yang tinggi untuk waktu yang lama. Nilai rata-rata organoleptik daging pada ketiga perlakuan perendaman konsentrasi ekstrak yang berbeda di jam 0 adalah 9 (Gambar 4). Hal ini menunjukkan bahwa pada penyimpanan 0 jam, ikan termasuk dalam kategori sangat segar dan tidak ada perbedaan, karena secara organoleptik ikan masih segar dan secara spesifik daging terlihat masih segar jika ditekan tidak lembek dan kembali ke bentuk semula.

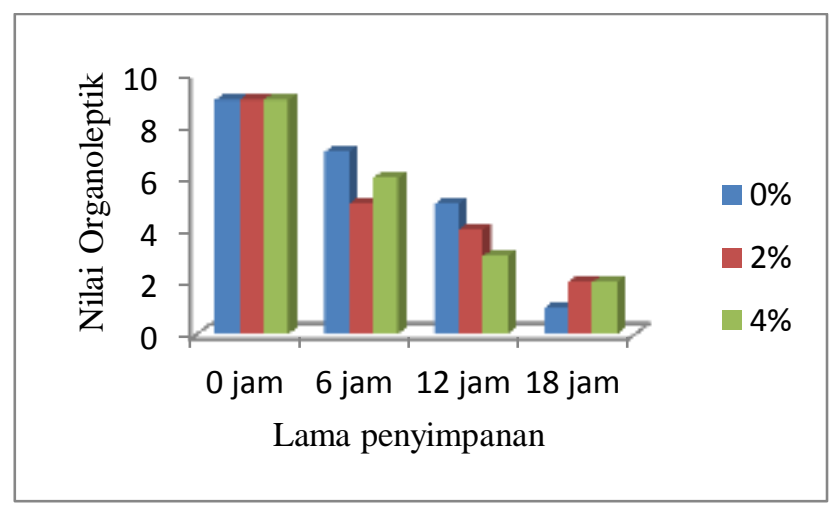

Gambar 4. Histogram penilaian organoleptik pada daging (meat)

Pada penyimpanan 6 jam, terlihat bahwa ikan dengan perendaman $0 \%$ memiliki nilai rata-rata sama yaitu 7,00. Terlihat kondisi daging sedikit merah, bau masih spesifik dan dinding perut masih utuh. Ikan dengan perendaman $2 \%$ memiliki nilai rata-rata yaitu 5,00 yang secara spesifik terlihat warna daging mulai pudar, adanya pemerahan sepanjang tulang belakang, mulai berbau busuk dan bila ditekan dengan jari akan tampak bekas lekukan. Sedangkan ikan dengan perendaman $4 \%$ memiliki nilai rata-rata 6,90 dimana terlihat warna daging kurang cemerlang, bau daging masih spesifik jenis, belum ada pemerahan sepanjang tulang belakang dan dinding perut masih utuh.

Pada penyimpanan 12 jam, terlihat bahwa ikan dengan perendaman $0 \%$ memiliki nilai rata-rata 5,00 dengan ciri-ciri daging mulai pudar, banyak pemerahan sepanjang tulang belakang dan dinding perut agak lunak. Ikan dengan perendaman $2 \%$ memiliki rata-rata yaitu 4,00 yang terlihat ciri-ciri daging pudar, warna merah jelas sekali sepanjang tulang belakang dan bila ditekan tampak bekas lekukan. Sedangkan untuk ikan dengan perendaman $4 \%$ memiliki nilai rata-rata 3,00 yang organoleptik daging berwarna kusam sekali, warna merah sangat jelas sekali sepanjang tulang belakang dan dinding perut sangat lunak.

Pada penyimpanan 18 jam, ikan dengan perendaman $0 \%$ memiliki nilai rata-rata 1,00 dimana daging berwarna sangat kusam sekali, warna merah jelas terlihat sepanjang tulang belakang dan dinding perut sangat lunak, serta berbau busuk yang menyengat. Ikan dengan perendaman $2 \%$ dan $4 \%$ memiliki nilai rata-rata 2,00 yang organoleptik daging ikan berwarna kusam, warna merah jelas sekali pada tulang belakang dan dinding perut lunak. Menurut Adawyah (2008), kualitas ikan ditentukan oleh dagingnya. Ikan yang masih segar, berdaging kenyal, jika ditekan dengan telunjuk atau ibu jari maka bekasnya akan segera kembali.

\section{Bau}

Nilai rata-rata organoleptik bau untuk ketiga perlakuan perendaman konsentrasi ekstrak yang berbeda pada jam 0 adalah 9 (Gambar 5). Hal ini menunjukkan bahwa penyimpanan 0 jam pada ikan kuwe termasuk dalam kategori sangat segar dan tidak ada perbedaan, karena secara organoleptik bau ikan sangat segar dan spesifik jenis.

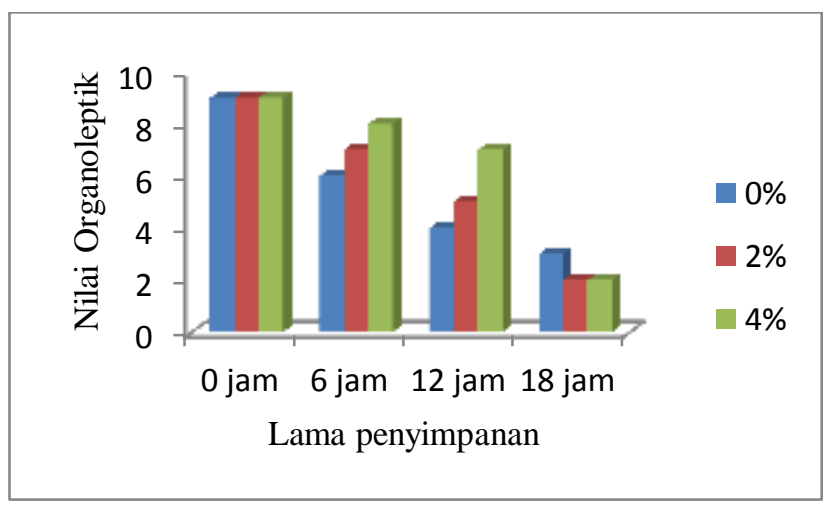

Gambar 5. Histogram penilaian organoleptik pada bau (odor) 
Pada penyimpanan 6 jam, terlihat bahwa ikan dengan perendaman $0 \%$ memiliki nilai rata-rata sama yaitu sebesar 5,90. Secara organoleptik, bau amoniak mulai tercium dan sedikit bau asam. Ikan dengan perendaman $2 \%$ memiliki rata-rata yaitu 7,00 yang secara organoleptik tercium bau netral dan belum tercium bau asam. Sedangkan untuk ikan dengan perendaman $4 \%$ memiliki nilai rata-rata 8,90 dengan bau masih segar dan spesifik jenis.

Pada penyimpanan 12 jam, terlihat bahwa ikan dengan perendaman $0 \%$ memiliki nilai rata-rata 3,00 yang organoleptik bau tercium amoniak kuat, sudah berbau asam dan busuk. Ikan dengan perendaman $2 \%$ memiliki nilai rata-rata yaitu 5,00 yang organoleptik bau amoniak mulai tercium dan sedikit berbau asam. Sedangkan untuk ikan dengan perendaman $4 \%$ memiliki nilai rata-rata 7,00 yang organoleptik bau netral atau bau segar sudah mulai menghilang dan belum ada bau asam. Hal ini menunjukkan bahwa pada penyimpanan 12 jam secara organoleptik bau ikan dengan perendaman $4 \%$ masih diterima oleh panelis.

Pada penyimpanan 18 jam, terlihat ikan dengan perendaman $0 \%$ memiliki nilai rata-rata 2,00 dengan ciri-ciri berbau busuk dan amoniak, serta memiliki kesan ditolak oleh panelis. Ikan dengan perendaman $2 \%$ memiliki rata-rata 4,00 yang organoleptik bau amoniak cukup kuat dan sudah berbau asam. Sedangkan ikan dengan perendaman $4 \%$ memiliki nilai rata-rata 5,95 yang organoleptik bau amoniak mulai tercium, dan sedikit berbau asam. Menurut Junianto (2003), perubahan yang terjadi pada bau ikan karena penguraian protein dari aktivitas bakteri, sehingga hubungan antara jumlah bakteri dengan bau pada ikan berbanding lurus.

\section{Tekstur}

Nilai rata-rata organoleptik tekstur untuk ketiga perlakuan perendaman konsentrasi ekstrak yang berbeda pada jam 0 adalah sebesar 9 (Gambar 6). Hal ini menunjukkan bahwa penyimpanan 0 jam, ikan termasuk dalam kategori sangat segar dan tidak ada perbedaan, karena secara organoleptik tekstur padat, elastis bila ditekan dengan jari dan daging sulit tersobek dari tulang belakang.

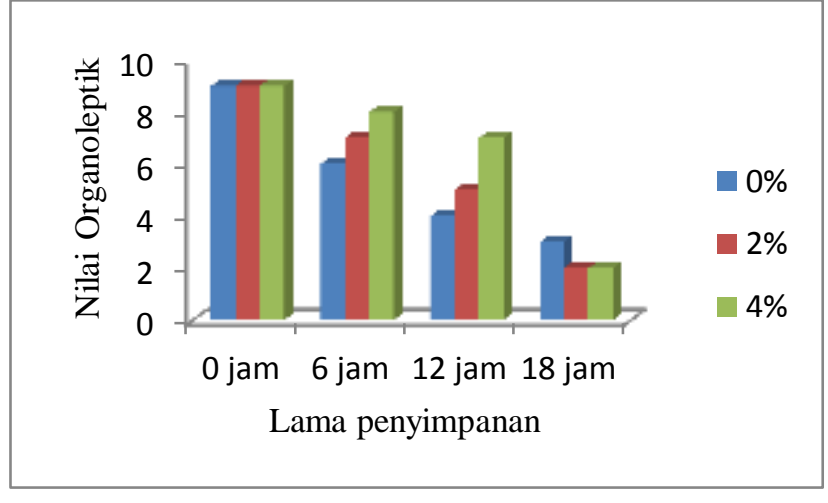

Gambar 6. Histogram penilaian organoleptik pada tekstur (texture)

Pada penyimpanan 6 jam, terlihat bahwa ikan dengan perendaman $0 \%$ memiliki nilai rata-rata yaitu 5,90 yang secara organoleptik tekstur agak lunak, kurang elastis lagi bila ditekan dengan jari dan daging agak mudah tersobek dari tulang belakang. Ikan dengan perendaman $2 \%$ memiliki nilai rata-rata yaitu 7,00 yang secara organoleptik tekstur agak padat, elastis bila ditekan dengan jari dan daging sulit tersobek dari tulang belakang. Sedangkan untuk ikan dengan perendaman $4 \%$ memiliki nilai rata-rata 8,00 yang organoleptik tekstur agak padat, elastis bila ditekan dengan jari dan daging masih sulit tersobek dari tulang belakang.

Pada penyimpanan 12 jam, terlihat bahwa ikan dengan perendaman $0 \%$ memiliki nilai rata-rata 3,95 yang organoleptik tekstur sudah lunak, bekas jari terlihat bila ditekan dan daging mudah tersobek dari tulang belakang. Ikan dengan perendaman $2 \%$ memiliki nilai rata-rata yaitu 4,90 yang organoleptik tekstur lunak, agak elastis bila ditekan dengan jari dan daging agak mudah tersobek dari tulang belakang. Sedangkan untuk ikan dengan perendaman $4 \%$ memiliki nilai rata-rata 6,95 yang organoleptik tekstur agak padat, agak elastis bila ditekan dengan jari dan daging sulit tersobek dari tulang belakang.

Pada penyimpanan 18 jam, terlihat ikan dengan perendaman $0 \%$ memiliki nilai rata-rata 3,00 yang organoleptik tekstur telah lunak, bekas jari terlihat bila ditekan dan daging modek tersobek dari tulang belakang. Ikan dengan perendaman $2 \%$ dan $4 \%$ memiliki nilai rata-rata yakni 2,00 yang organoleptik tekstur 
sangat lunak, bekas jari tidak hilang bila ditekan dan sangat mudah sekali tersobek. Hal ini disebabkan karena terjadinya perombakan pada jaringan otot daging oleh proses enzimatis (Wibowo, dkk., 2014). Ditambahkan oleh pernyataan Suwetja (2011) dalam Pianusa, $d k k$. (2015), bahwa penguraian oleh bakteri mulai berlangsung insentif setelah tahap rigormotis berlalu, yaitu setelah daging ikan tidak lagi kompak.

\section{KESIMPULAN DAN SARAN}

Berdasarkan hasil penelitian yang dilakukan maka dapat disimpulkan bahwa hasil penilaian mutu organoleptik ikan kuwe (Gnathanodon speciosus) segar dalam perlakuan perendaman ekstrak daun mangrove (Sonneratia caseolaris) dengan konsentrasi 2\%4\% dapat mempertahankan daya simpan lebih baik. Hal ini karena peran senyawa metabolik sekunder yang dapat menghambat pertumbuhan mikroba yang terkandung pada daun mangrove. Selain itu perendaman dalam ekstrak daun mangrove juga dapat mempertahankan nilai organoleptik ikan.

Saran yang dapat diberikan berdasarkan penelitian ini yaitu perlu dilakukan penelitian serupa terhadap jenis-jenis ikan yang lain.

\section{DAFTAR PUSATAKA}

Adawyah, R. 2008. Pengolahan dan Pengawetan Ikan. Bumi Aksara. Jakarta.

Girsang, D.Y., Azhari, R., Susilawati, 2014. Kasus Distribusi dan Penggunaan Formalin Dalam Pengawetan Komoditi Ikan Laut Segar (Studi Kasus di Kota Bandar Lampung). J. Tekn. dan Industri Hasil Pertanian 19 (3), 218-228.

Hasanah, S., Ahmad, I., Rijai, L. 2015. Profil Tabir Surya Ekstrak dan Fraksi Daun Pidada Merah (Sonneratia caseolaris L.). Jurnal Sains dan Kesehatan 1(4): 175 - 180.

Haryati, S. 2006. Optimalisasi Penggunaan Bawang Putih Sebagai Pengawet Alami Dalam Pengolahan IKan Asin Jambal Roti. Skripsi. Institut Pertanian Bogor.

Junianto, 2003. Teknik Penanganan Ikan. Jakarta. Penebar Swadaya.

Nurqaderianie, A.S., Metusalach, Fahrul. 2016. Tingkat Kesegaran Ikan Kembung Lelaki
(Rastrelliger kanagurta) yang Dijual Eceran Keliling di Kota Makassar. Jurnal IPTEKS PSP 3(6): 528-543.

Pariansyah, A., Nurlaila, E.H., Bertoka FSD Negara. 2018. Aplikasi Maserat Buah Mangrove Avicennia marina Sebagai Pengawet Alami Ikan Nila Segar. Acta Aquatica: Aquatic Sciences Journal 5(1): 36-44.

Pianusa, A.F., Grace, S., Wonggo, D., 2015. Kajian Perubahan Mutu Kesegaran Ikan Tongkol (Euthynnus affinis) Yang Direndam Dalam Ekstrak Rumput Laut (Eucheuma spinosum) dan Ekstrak Buah Bakau (Sonneratia alba). J. Media Tek. Hasil Perikanan 3 (2): 66-74.

Putro, S., Dwiyitno, J.F. Hidayat, M. Pandjaitan. Aplikasi Ekstrak Bawang Putih (Alium sativum) untuk Memperpanjang Daya Simpan Ikan Kembung Segar (Rastrelliger kanagurta). Jurnal Pascapanen dan Bioteknologi Kelautan dan Perikanan 3(2): 193-200.

Sadiki, V.T., A.S. Naiu, F.A. Dali. 2015. Mutu Organoleptik dan Mikrobiologis Ikan Tongkol yang Diawetkan dengan Bawang Putih Selama Penyimpanan Suhu Ruang. Jurnal Ilmiah Perikanan dan Kelautan 3(3): 94-99.

Saptiani, G., Prayitno, S.B., Anggoro, S. 2013. Potensi Antibakteri Ekstrak Daun Jeruju (Acanthus ilicifolius) Terhadap Vibrio harveyi Secara In Vitro. Jurnal Kedokteran Hewan 7(1) 17-20. DOI: https://doi.org/10.21157/ j.ked.hewan.v7i1.558.

Sipayung, B.S., Widodo, F.M., Eko, N.D., 2015. Pengaruh Senyawa Bioaktif Buah Mangrove Avicennia marina Terhadap Tingkat Oksidasi Fillet Ikan Nila Merah O. niloticus Selama Penyimpanan Dingin. J. Peng. dan Biotek. Has. Perik. 4 (2): 115-123.

SNI 01-2729.1-2006. Ikan Segar-Bagian 1: Spesifikasi. Badan Standarisasi Nasional. Jakarta. 10 pp.

Suprayitno, E. 2020. Kajian Kesegaran Ikan di Pasar Tradisional dan Modern Kota Malang. Journal of Fisheries and Marine Research 4(2): 289-295.

Tapotubun, A.M., I.K.E. Savitri, Th.E.A.A. Matrutty. 2016. Penghambatan Bakteri Patogen pada Ikan Segar yang Diaplikasi Caulerpa lentilifera. JPHPI 19(3): 299-308. DOI: 10.17844/jphpi.2016.19.3.299.

Tuyu, A., H. Onibala, D.M. Makepedua. 2014. Studi Lama Pengeringan Ikan Selar (Selaroides sp) Asin Dihubungakan dengan Kadar Air dan Nilai Organoleptik. Jurnal Media Teknologi Hasil Perikanan 2(2): 20-26. 
Wahyu, Y.I., P.S. Ariadi, J. Sayuti. 2019. Penilaian Mutu Secara Organoleptik Ikan Cakalang (Katsuwonus pelamis) di Pelabuhan Perikanan Pantai Pondokdadap Kabupaten Malang. Samakia: Jurnal Ilmu Perikanan 10(2): 66-72.
Wibowo, I.R., Y.S. Darmanto, A.D. Anggo. 2014. Pengaruh Cara Kematian dan Tahapan Penurunan Kesegaran Ikan Terhadap Kualitas Pasta Ikan Nila (Oreochromis niloticus). Jurnal Pengolahan dan Bioteknologi Hasil Perikanan 3(3): 95-103. 